\title{
Case fatality rate of COVID-19: a systematic review and meta-analysis
}

\author{
YOUSEF ALIMOHAMADI ${ }^{1,2}$, HABTEYES HAILU TOLA ${ }^{3}$, ABBAS ABBASI-GHAHRAMANLOO ${ }^{4}$ \\ MAJID JANANI ${ }^{2}$, MOJTABA SEPANDI ${ }^{5,6}$ \\ ${ }^{1}$ Pars Advanced and Minimally Invasive Medical Manners Research Center, Pars Hospital, Iran University of Medical Sciences, \\ Tehran, Iran; ${ }^{2}$ Department of Epidemiology \& Biostatistics, School of Public Health, Tehran University of Medical Sciences, Tehran, \\ Iran; ${ }^{3}$ Ethiopian Public Health Institute, TB/HIV Research Directorate, Addis Ababa, Ethiopia; ${ }^{4}$ Department of Public Health, Ardabil \\ University of Medical Science, Ardabil, Iran; ${ }^{5}$ Health Research Center, Life Style Institute, Baqiyatallah University of Medical \\ Sciences, Tehran, Iran; ${ }^{6}$ Department of Epidemiology \& Biostatistics, School of Health, Baqiyatallah University of Medical Sciences, \\ Tehran, Iran
}

Keywords

Case fatality rate $\bullet$ COVID-19 $\bullet$ Meta-analysis $\bullet$ Epidemic $\bullet$ Epidemiology

\section{Summary}

Objective. The ongoing novel coronavirus disease 2019 (COVID19 ) is the leading cause of morbidity and mortality due to its contagious nature and absence of vaccine and treatment. Although numerous primary studies reported extremely variable case fatality rate (CFR) of COVID-19, no review study attempted to estimate the CFR of COVID-19. The current systematic review and meta-analysis were aimed to assess the pooled CFR of COVID-19. Methods. Electronic databases: PubMed, Science Direct, Scopus, and Google Scholar were searched to retrieve the eligible primary studies that reported CFR of COVID-19. Keywords: ("COVID19"OR "COVID-2019" OR "severe acute respiratory syndrome coronavirus 2"OR "severe acute respiratory syndrome coronavirus 2" OR "2019-nCoV" OR "SARS-CoV-2" OR "2019nCoV" OR (("Wuhan" AND ("coronavirus" OR "coronavirus")) AND (2019/12[PDAT] OR 2020[PDAT]))) AND ("mortality "OR "mortality" OR ("case" AND "fatality" AND "rate") OR "case fatality rate") were used as free text and MeSH term in searching

\section{Introduction}

The ongoing coronavirus 2019 (COVID-19) was initially reported from Wuhan, China, in December 2019. After few weeks, it has been involved in several countries and became a significant global public health problem [1-3]. World Health Organization (WHO) designated COVID-19 as a pandemic disease on March 11, 2020 (WHO, situational Report-52). The most known symptoms of COVID-19 are fever, cough, shortness of breathing, and occasional watery diarrhea [4]. Even though COVID-19 often causes mild symptoms compared to other respiratory infections, it can cause severe illness in certain groups of people, such as the elderly and people with major underlying health problems (cardiovascular disease and diabetes) [5].

There are two key parameters to understand the epidemiological features of an outbreak or epidemic. These are primary reproduction numbers $\left(R_{0}\right)$ and casefatality rates (CFR) [6, 7]. The $\mathrm{R}_{0}$ is an epidemiologic metric that has been used to assess the infectiveness of process. A random-effects model was used to estimate the CFR in this study. $I^{2}$ statistics, Cochran's $Q$ test, and $T^{2}$ were used to assess the functional heterogeneity between included studies.

Results. The overall pooled CFR of COVID 19 was $10.0 \%(95 \%$ CI: 8.0-11.0); $\left.P<0.001 ; I^{2}=99.7\right)$. The pooled CFR of COVID19 in general population was 1.0\% (95\% CI: 1.0-3.0); $P<0.001$; $I^{2}=94.3$ ), while in hospitalized patients was 13.0\% (95\% CI: 9.017.0); $P<0.001, I^{2}=95.6$ ). The pooled CFR in patients admitted in intensive care unit (ICU) was $37.0 \%$ (95\% CI: 24.0-51.0); $\left.P<0.001, I^{2}=97.8\right)$ and in patients older than 50 years was 19.0\% (95\% CI: 13.0-24.0); $P<0.001 ; I^{2}=99.8$ ).

Conclusion. The present review results highlighted the need for transparency in testing and reporting policies and denominators used in CFR estimation. It is also necessary to report the case's age, sex, and the comorbidity distribution of all patients, which essential in comparing the CFR among different segments of the population.

the agents that cause an outbreak. This index explains the average number of new cases generated from an infected person. The higher amount of $\mathrm{R}_{0}$ indicates the highest transmissibility of the infection agent. An estimated $\mathrm{R}_{0}$ of the COVID-19 virus is 3.32 , which means one infected case can transmit the virus to 3 to 4 susceptible individuals [8]. CFR is another essential index that helps to understand the epidemiological characteristics of an outbreak. The CFR of COVID-19 is defined as the number of deaths in COVID-19 cases divided by the total number of people infected by COVID-19 [9]. Previously reported CFR of COVID-19 is highly variable. The primary cause of this heterogeneity could be varied as a result of surveillance systems sensitivity. Surveillance system sensitivity low due to more than $80 \%$ of cases does not show symptoms of the disease or show mild symptoms. Thus, cases missed by the surveillance system are not considered in the denominator and could lead to overestimation of CFR $[10,11]$. Several primary studies have been conducted to estimate the CFR of COVID-19 across the world and reported extremely heterogeneous 
magnitude. However, no review study has attempted to estimate pooled CRF of COVID-19 from the available literature to understand better the nature of an outbreak and the virulence of the disease. Thus, the current study was aimed to estimate pooled CFR of COVID-19 from primary studies reported from different countries using systematic review and meta-analysis.

\section{Materials and methods}

\section{SEARCH STRATEGY}

This systematic review and meta-analysis were performed to estimate pooled CRF of COVID-19 from the primary studies published in international electronic databases. Electronic databases: PubMed, Scopus, Science Direct, and Google Scholar were searched to retrieve eligible studies that were conducted to estimate CFR of COVID-19. Keywords: ("COVID19"OR “COVID-2019” OR "severe acute respiratory syndrome coronavirus 2"OR "severe acute respiratory syndrome coronavirus 2" OR "2019-nCoV" OR "SARS-CoV-2" OR "2019nCoV" OR (("Wuhan" AND ("coronavirus" OR "coronavirus")) AND (2019/12[PDAT] OR 2020[PDAT]))) AND ("mortality "OR "mortality" OR ("case" AND "fatality" AND "rate") OR "case fatality rate") were used in free text and $\mathrm{MeSH}$ terms.

\section{STUDY SELECTION AND DATA EXTRACTION}

All studies published in 2020 and reported CFR for COVID-19 were included in this review (Fig. 1). From each included study, extracted information on the first author's name, the country from where the study was reported, year of study, sample size, type of study, age, gender, comorbidity, and CFR with a $95 \%$ confidence interval (Tab. I and II).

\section{STATISTICAL ANALYSIS}

Cochran's Q test's heterogeneity in the CFR of COVID-19 between different studies was assessed with a significance level of $\mathrm{P}<0.1$ and $\mathrm{I}^{2}$ statistic with values $>75 \%$ [12]. A random-effects meta-analysis model was used to estimate pooled CFR because of the presence of high heterogeneity $\left(\mathrm{I}^{2}=99.7 \%\right.$ and Cochran's $\mathrm{Q}(\mathrm{p}<0.001)$. The univariate metaregression model was used to assess the effect of sample size on the heterogeneity of pooled CFR. Publication bias was evaluated by Beggs and Eggers tests. Also, the risk of bias analysis performed using the Newcastle-Ottawa Scale for observational studies [13]. Data were analyzed by STATA v 11 (StataCorp, College Station, TX, USA).

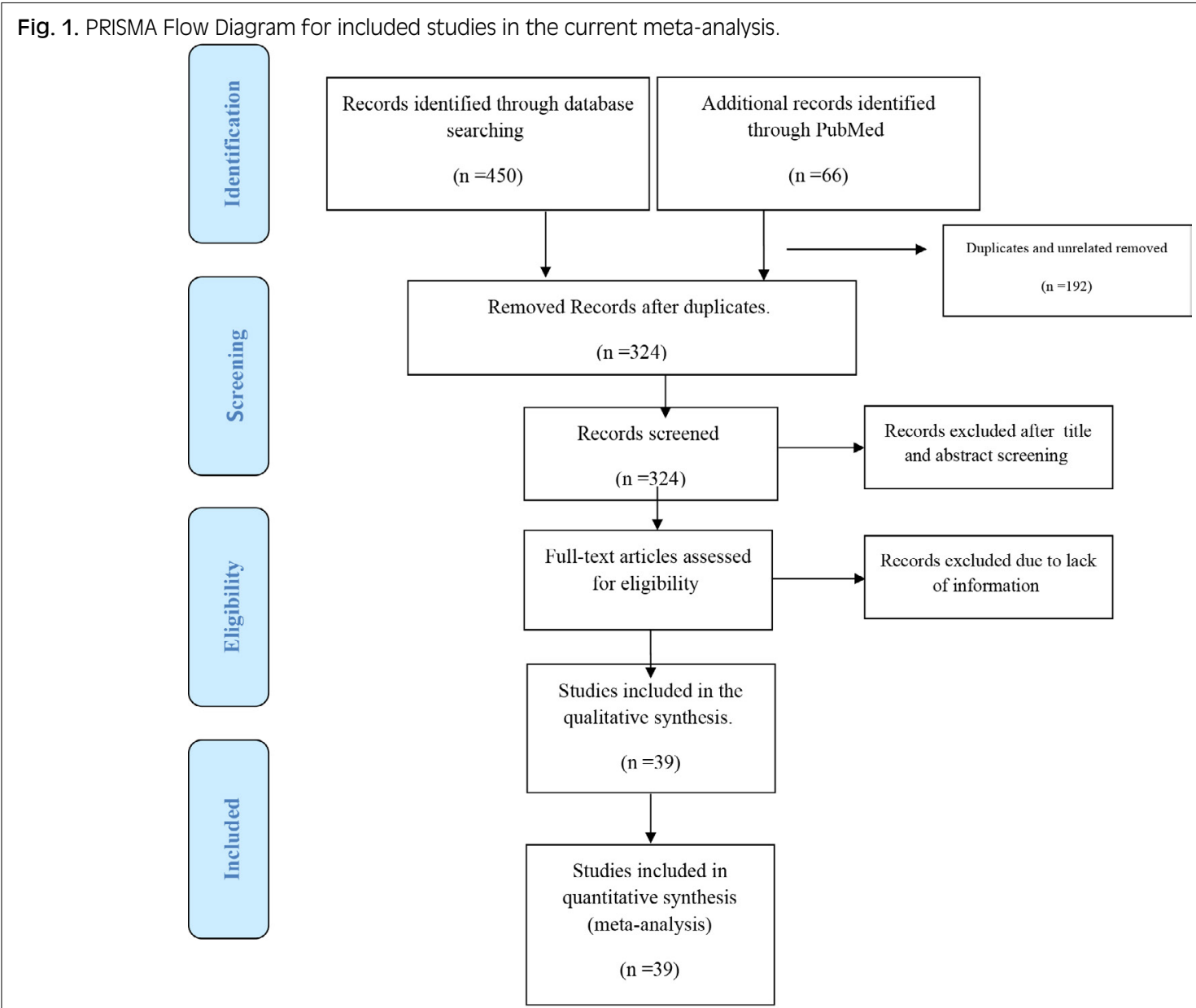


Tab. I. Included studies in the current meta-analysis.

\begin{tabular}{|c|c|c|c|c|c|c|c|}
\hline $\begin{array}{l}\text { The first } \\
\text { author } \\
\text { (publication } \\
\text { year) }\end{array}$ & Country & $\begin{array}{l}\text { Sample } \\
\text { size }\end{array}$ & $\begin{array}{c}\text { Sex of } \\
\text { participant }\end{array}$ & $\begin{array}{c}\text { Mean/ } \\
\text { med } \\
\text { of age }\end{array}$ & $\begin{array}{l}\text { Study design } \\
\text { (randomization, blinding) }\end{array}$ & study based & $\begin{array}{l}\text { CFR } \\
\text { estimation }\end{array}$ \\
\hline $\begin{array}{l}\text { Wang et al. } \\
\text { (2020) [13] }\end{array}$ & China & 138 & Both & 58 & $\begin{array}{l}\text { Retrospective single-center } \\
\text { case series }\end{array}$ & Hospitalized & 0.043 \\
\hline $\begin{array}{l}\text { Grasselli et al. } \\
(2020)[14]\end{array}$ & Italy & 1591 & Both & 63 & Retrospective, case series & ICU, Hospitalized, Total & 0.26 \\
\hline $\begin{array}{l}\text { Grasselli et al. } \\
\text { (2020) [14] }\end{array}$ & Italy & 786 & Both & $64<=$ & Retrospective, case series & ICU, Hospitalized & 0.36 \\
\hline $\begin{array}{l}\text { Grasselli et al. } \\
\text { (2020) [14] }\end{array}$ & Italy & 795 & Both & $<=63$ & Retrospective, case series & ICU, Hospitalized & 0.15 \\
\hline $\begin{array}{l}\text { Guo et al. (2020) } \\
\text { [15] }\end{array}$ & China & 187 & Both & 58.5 & $\begin{array}{l}\text { Retrospective, single-center } \\
\text { case series }\end{array}$ & Hospitalized & 0.23 \\
\hline $\begin{array}{l}\text { Wei et al. (2020) } \\
\text { [16] }\end{array}$ & China & 1975 & Both & & Cross-sectional & Unknown & 0.0284 \\
\hline $\begin{array}{l}\text { Yin et al. (2020) } \\
\text { [17] }\end{array}$ & China & 449 & Both & 65.1 & Retrospective-cohort & Hospitalized & 0.298 \\
\hline $\begin{array}{l}\text { Chen et al. } \\
(2020)[18]\end{array}$ & China & 99 & Both & 55.5 & $\begin{array}{c}\text { Retrospective, single-center } \\
\text { study }\end{array}$ & Hospitalized & 0.11 \\
\hline $\begin{array}{l}\text { Xiaobo Yang et } \\
\text { al. (2020)[19] }\end{array}$ & China & 52 & Both & 59.7 & Retrospective observational & ICU, Hospitalized & 0.615 \\
\hline $\begin{array}{l}\text { Zhou et al. } \\
\text { (2020) [20] }\end{array}$ & china & 191 & Both & 56 & Retrospective cohort & Hospitalized & 0.2827 \\
\hline $\begin{array}{l}\text { Barrasa et al. } \\
(2020)[21]\end{array}$ & Spain & 48 & Both & 63 & Cross-sectional & ICU, Hospitalized & 0.13 \\
\hline $\begin{array}{l}\text { Tang et al. (2020) } \\
\text { [22] }\end{array}$ & China & 179 & & 67 & Retrospective case-control & Hospitalized & 0.288 \\
\hline $\begin{array}{l}\text { Lei et al (2020) } \\
\text { [23] }\end{array}$ & China & 34 & Both & 55 & Retrospective review patient & Hospitalized, Total & 0.206 \\
\hline $\begin{array}{l}\text { Lei et al (2020) } \\
\text { [23] }\end{array}$ & China & 15 & Both & 55 & Retrospective review patient & ICU admitted & 0.467 \\
\hline $\begin{array}{l}\text { Lei et al (2020) } \\
\text { [23] }\end{array}$ & China & 19 & Both & 47 & Retrospective review patient & Hospitalized & 0 \\
\hline $\begin{array}{l}\text { Shim et al. } \\
\text { (2020) [5] }\end{array}$ & $\begin{array}{l}\text { South- } \\
\text { Korea }\end{array}$ & 6284 & Both & NR & Cross-sectional & $\begin{array}{c}\text { General Population, } \\
\text { Total }\end{array}$ & 0.007 \\
\hline $\begin{array}{l}\text { Shim et al. } \\
\text { (2020) [5] }\end{array}$ & $\begin{array}{l}\text { South- } \\
\text { Korea }\end{array}$ & 2345 & Male & NR & Cross-sectional & General Population & 0.011 \\
\hline $\begin{array}{l}\text { Shim et al. } \\
(2020)[5]\end{array}$ & $\begin{array}{l}\text { South- } \\
\text { Korea }\end{array}$ & 3939 & Female & NR & Cross-sectional & General Population & 0.004 \\
\hline $\begin{array}{l}\text { Li et al (2020) } \\
\text { [24] }\end{array}$ & China & 279 & Both & 56 & Ambispective cohort study & Hospitalized & 0.011 \\
\hline $\begin{array}{l}\text { Li et al (2020) } \\
{[24]}\end{array}$ & China & 269 & Both & 65 & Ambispective cohort study & ICU admitted & 0.325 \\
\hline $\begin{array}{l}\text { Tian et al. (2020) } \\
\text { [25] }\end{array}$ & China & 262 & Both & 47.5 & Retrospective & Hospitalized & 0.009 \\
\hline $\begin{array}{l}\text { Tian et al. (2020) } \\
\text { [25] }\end{array}$ & China & 46 & Both & 61.4 & Retrospective & Hospitalized & 0.065 \\
\hline $\begin{array}{l}\text { Tian et al. (2020) } \\
\text { [25] }\end{array}$ & China & 216 & Both & 44.5 & Retrospective & General Population & 0 \\
\hline $\begin{array}{l}\text { Liu et al. (2020) } \\
\text { [26] }\end{array}$ & China & 56 & Both & NR & Retrospective study & Hospitalized, Total & NR \\
\hline $\begin{array}{l}\text { Liu et al. (2020) } \\
\text { [26] }\end{array}$ & China & 18 & Both & 68 & Retrospective study & Hospitalized & 0.0556 \\
\hline $\begin{array}{l}\text { Liu et al. (2020) } \\
\text { [26] }\end{array}$ & China & 38 & Both & 47 & Retrospective study & Hospitalized & 0.0526 \\
\hline $\begin{array}{l}\text { Liu et al. (2020) } \\
\text { [27] }\end{array}$ & China & 245 & Both & 43.95 & Retrospective cohort & Hospitalized & 0.1347 \\
\hline $\begin{array}{l}\text { Lei et al (2020) } \\
\text { [28] }\end{array}$ & China & 20 & Both & 43.2 & Cross-sectional & Hospitalized & 0 \\
\hline $\begin{array}{l}\text { Sun et al. (2020) } \\
\text { [29] }\end{array}$ & China & 288 & Both & 44 & Cross-sectional & Unknown & 0.135 \\
\hline
\end{tabular}


Tab. I. Included studies in the current meta-analysis.

\begin{tabular}{|c|c|c|c|c|c|c|c|}
\hline $\begin{array}{l}\text { The first } \\
\text { author } \\
\text { (publication } \\
\text { year) }\end{array}$ & Country & $\begin{array}{l}\text { Sample } \\
\text { size }\end{array}$ & $\begin{array}{c}\text { Sex of } \\
\text { participant }\end{array}$ & $\begin{array}{c}\text { Mean/ } \\
\text { med } \\
\text { of age }\end{array}$ & $\begin{array}{c}\text { Study design } \\
\text { (randomization, blinding) }\end{array}$ & study based & $\begin{array}{c}\text { CFR } \\
\text { estimation }\end{array}$ \\
\hline $\begin{array}{l}\text { Mei et al (2020) } \\
{[30]}\end{array}$ & World & 96580 & Both & & Cross-sectional & Unknown & 0.0363 \\
\hline $\begin{array}{l}\text { Cao et al. et al. } \\
\text { (2020) [31] }\end{array}$ & China & 199 & Both & 58 & $\begin{array}{c}\text { Randomized, controlled, open- } \\
\text { label trial }\end{array}$ & Hospitalized & 0.161 \\
\hline $\begin{array}{l}\text { Cao et al. (2020) } \\
\text { [31] }\end{array}$ & China & 99 & Both & 58 & $\begin{array}{l}\text { Randomized, controlled, open- } \\
\text { label trial }\end{array}$ & Hospitalized & 0.152 \\
\hline $\begin{array}{l}\text { Cao et al. (2020) } \\
\text { [31] }\end{array}$ & China & 100 & Both & 58 & $\begin{array}{c}\text { Randomized, controlled, open- } \\
\text { label trial }\end{array}$ & Hospitalized & 0.17 \\
\hline $\begin{array}{l}\text { Bhatraju et al. } \\
\text { (2020) [32] }\end{array}$ & USA & 24 & Both & 64 & Retrospective case series & Hospitalized & 0.5 \\
\hline $\begin{array}{l}\text { Grein et al. } \\
\text { (2020) [33] }\end{array}$ & $\begin{array}{c}\text { USA, } \\
\text { Canada, } \\
\text { Europe, } \\
\text { Japan }\end{array}$ & 53 & Both & 64 & Cohort & Hospitalized & 0.13 \\
\hline $\begin{array}{l}\text { Grein et al. } \\
(2020)[33]\end{array}$ & $\begin{array}{l}\text { USA, } \\
\text { Canada, } \\
\text { Europe, } \\
\text { Japan }\end{array}$ & 34 & Both & 67 & Cohort & Hospitalized & 0.18 \\
\hline $\begin{array}{l}\text { Grein et al. } \\
\text { (2020) [33] }\end{array}$ & $\begin{array}{l}\text { USA, } \\
\text { Canada, } \\
\text { Europe, } \\
\text { Japan }\end{array}$ & 19 & Both & 53 & Cohort & Hospitalized & 0.05 \\
\hline $\begin{array}{l}\text { Liang et al. } \\
\text { (2020) [34] }\end{array}$ & China & 1590 & Both & 48.9 & Retrospective cohort & General Population & 0.031 \\
\hline $\begin{array}{l}\text { Liang et al. } \\
(2020)[34]\end{array}$ & China & 647 & Both & 55.1 & Retrospective cohort & General Population & 0.073 \\
\hline $\begin{array}{l}\text { Liang et al. } \\
\text { (2020) [34] }\end{array}$ & China & 943 & Both & 44.6 & Retrospective cohort & General Population & 0.003 \\
\hline $\begin{array}{l}\text { Gao et al. (2020) } \\
\text { [35] }\end{array}$ & China & 54 & Both & 60.4 & Cohort & Hospitalized & 0.333 \\
\hline $\begin{array}{l}\text { Du et al. (2020) } \\
\text { [36] }\end{array}$ & China & 109 & Both & 70.7 & Multi-center observational & $\mathrm{ICU}$ & 0.661 \\
\hline $\begin{array}{l}\text { Du et al. (2020) } \\
\text { [36] }\end{array}$ & China & 51 & Both & 68.4 & Multi-center observational & $\mathrm{ICU}$ & 0.706 \\
\hline $\begin{array}{l}\text { Du et al. (2020) } \\
\text { [36] }\end{array}$ & China & 58 & Both & 72.7 & Multi-center observational & Hospitalized & 0.620 \\
\hline $\begin{array}{l}\text { Xiao-Wei Xu et } \\
\text { al. (2020) [37] }\end{array}$ & China & 62 & Both & 41 & Retrospective study & Hospitalized & 0 \\
\hline $\begin{array}{l}\text { Cai et al (2020) } \\
\text { [38] }\end{array}$ & $\begin{array}{l}\text { Hong- } \\
\text { Kong }\end{array}$ & 298 & Both & 47.5 & Retrospective study & $\begin{array}{c}\text { General Population, } \\
\text { Total }\end{array}$ & 0.01 \\
\hline $\begin{array}{l}\text { Cai et al (2020) } \\
{[38]}\end{array}$ & $\begin{array}{l}\text { Hong- } \\
\text { Kong }\end{array}$ & 240 & Both & 41 & Retrospective study & General Population & 0 \\
\hline $\begin{array}{l}\text { Cai et al (2020) } \\
\text { [38] }\end{array}$ & $\begin{array}{l}\text { Hong- } \\
\text { Kong }\end{array}$ & 58 & Both & 62.5 & Retrospective study & General Population & 0.052 \\
\hline $\begin{array}{l}\text { Cao et al. (2020) } \\
\text { [39] }\end{array}$ & China & 102 & Both & 54 & Cohort & Hospitalized & 0.167 \\
\hline $\begin{array}{l}\text { Liu et al. (2020) } \\
\text { [40] }\end{array}$ & China & 137 & Both & 57 & Retrospective & Hospitalized & 0.118 \\
\hline $\begin{array}{l}\text { Young et al. } \\
\text { (2020) [41] }\end{array}$ & Singapore & 18 & Both & 47 & Case-series & Hospitalized, Total & 0 \\
\hline $\begin{array}{l}\text { Young et al. } \\
\text { (2020) [41] }\end{array}$ & Singapore & 12 & Both & 37 & Case-series & Hospitalized & 0 \\
\hline $\begin{array}{l}\text { Young et al. } \\
\text { (2020) [41] }\end{array}$ & Singapore & 6 & Both & 56 & Case-series & Hospitalized & 0 \\
\hline $\begin{array}{l}\text { Wang et al. } \\
\text { (2020) [42] }\end{array}$ & China & 69 & Both & 42 & Retrospective review patient & Hospitalized & 0.075 \\
\hline $\begin{array}{l}\text { Jian Wu et al. } \\
\text { (2020) [2] }\end{array}$ & China & 80 & Both & 46.1 & Retrospective & Hospitalized & 0 \\
\hline
\end{tabular}


Tab. I. Included studies in the current meta-analysis.

\begin{tabular}{|c|c|c|c|c|c|c|c|}
\hline $\begin{array}{l}\text { The first } \\
\text { author } \\
\text { (publication } \\
\text { year) }\end{array}$ & Country & $\begin{array}{c}\text { Sample } \\
\text { size }\end{array}$ & $\begin{array}{c}\text { Sex of } \\
\text { participant }\end{array}$ & $\begin{array}{c}\text { Mean/ } \\
\text { med } \\
\text { of age }\end{array}$ & $\begin{array}{l}\text { Study design } \\
\text { (randomization, blinding) }\end{array}$ & Study based & $\begin{array}{c}\text { CFR } \\
\text { estimation }\end{array}$ \\
\hline $\begin{array}{l}\text { McMichael et al. } \\
\text { (2020) [43] }\end{array}$ & USA & 167 & Both & 72 & Cross-sectional & Ceneral Population & 0.21 \\
\hline $\begin{array}{l}\text { Yanli Liu et al. } \\
\text { (2020) [44] }\end{array}$ & China & 383 & Both & 46 & Retrospective cohort & Hospitalized & 0.128 \\
\hline $\begin{array}{l}\text { Yanli Liu et al. } \\
\text { (2020) [44] }\end{array}$ & China & 68 & Both & 52 & Retrospective cohort & Hospitalized & 0.309 \\
\hline $\begin{array}{l}\text { Yanli Liu et al. } \\
\text { (2020) [44] }\end{array}$ & China & 315 & Both & 43 & Retrospective cohort & Hospitalized & 0.089 \\
\hline $\begin{array}{l}\text { Chen et al. } \\
\text { (2020) [45] }\end{array}$ & China & 203 & Both & 54 & Retrospective case series & Hospitalized & 0.128 \\
\hline $\begin{array}{l}\text { Ning Tang et al. } \\
\text { (2020) [46] }\end{array}$ & China & 183 & Both & 54.1 & Cross-sectional & Hospitalized & 0.115 \\
\hline $\begin{array}{l}\text { Morteza } \\
\text { Abdullatif } \\
\text { Khafaie et al. } \\
2020 \text { [47] }\end{array}$ & World & 337570 & Both & & Retrospective-cohort & Unknown & 0.0434 \\
\hline $\begin{array}{l}\text { Huang et al. } \\
\text { (2020) [48] }\end{array}$ & China & 41 & Both & 49 & Prospective & Total & 0.15 \\
\hline $\begin{array}{l}\text { Huang et al. } \\
\text { (2020) [48] }\end{array}$ & China & 13 & Both & 49 & Prospective & $\mathrm{ICU}$ & 0.38 \\
\hline $\begin{array}{l}\text { Huang et al. } \\
\text { (2020) [48] }\end{array}$ & China & 28 & Both & 49 & Prospective cohort & Hospitalized & 0.04 \\
\hline $\begin{array}{l}\text { Wei-Jie Guan et } \\
\text { al. (2020) [49] }\end{array}$ & China & 926 & Both & 45 & Retrospective & General Population & 0.001 \\
\hline $\begin{array}{l}\text { Wei-Jie Guan et } \\
\text { al. (2020) [49] }\end{array}$ & China & 173 & Both & 52 & Retrospective & General Population & 0.081 \\
\hline $\begin{array}{l}\text { Nikpouraghdam } \\
\text { et al. (2020) [1] }\end{array}$ & Iran & 2964 & Both & 55.5 & Retrospective & Hospitalized & 0.086 \\
\hline $\begin{array}{l}\text { Nikpouraghdam } \\
\text { et al. (2020) [1] }\end{array}$ & Iran & 2964 & Both & 55.5 & Retrospective & General Population & 0.018 \\
\hline
\end{tabular}

Tab. II. The estimated case fatality rate of COVID-19 in different subgroups.

\begin{tabular}{|l|c|c|c|c|}
\hline Group & Pooled estimation (\%) & $95 \% \mathrm{Cl}$ & $\mathbf{Q}$ & $\mathrm{I}^{\mathbf{2}(\%)}$ \\
\hline General population & 1.00 & $1.0-3.0$ & $\mathrm{P}<0.001$ & 94.3 \\
\hline Hospitalized patients & 13.0 & $9.0-17.0$ & $\mathrm{P}<0.001$ & 95.6 \\
\hline ICU admitted & 37.0 & $24.0-51.0$ & $\mathrm{P}<0.001$ & 97.8 \\
\hline Unknown & 4.0 & $3.0-5.0$ & $\mathrm{P}<0.001$ & 97.8 \\
\hline$\leq 50$ & 3.0 & $0.0-6.0$ & $\mathrm{P}<0.001$ & 93.7 \\
\hline$>50$ & 19.0 & $13.0-24.0$ & $\mathrm{P}<0.001$ & 98.1 \\
\hline Unknown & 2.0 & $1.0-3.0$ & $\mathrm{P}<0.001$ & 99.8 \\
\hline Overall & 10.0 & $8.0-11.0$ & $\mathrm{P}<0.001$ & 99.7 \\
\hline
\end{tabular}

\section{Results}

Figure 1 depicts the study selection procedure. A total of 516 records were retrieved through electronic databases search, and 324 identified articles after removing 192 pieces due to duplication and irrelevance for the review purpose. The second stape 236 articles were excluded after the title and abstract screeded for the inclusion and exclusion criteria. Of the remaining 88 articles, 49 articles were excluded due to a lack of relevant information or not original articles. Finally, 39 articles reported CFR of COVID-19 were included in the final analysis (Fig. 1 and Table 1).

The Median and IQR( Interquartile range) of reported CFR rate were $8.7 \%(23.0-1.0)$. The Minimum and Maximum reported CFR were 0 and $70.6 \%$ respectivly (Fig. 2). The overall pooled estimated CFR of COVID-19 was $10.0 \%$ (95\% CI: 8.0-11.0; $\mathrm{P}<0.001, \mathrm{I}^{2}=99.7$ ) (Fig. 2). The pooled estimated CFR of COVID-19 among general population was $1.0 \%$ (95\% CI: 1.0-3.0; $\left.\mathrm{P}<0.001, \mathrm{I}^{2}=94.3\right)$, while in hospitalised patients $13.0 \%$ (95\% CI: 9.0-17.0; $\mathrm{P}<0.001$, $\left.\mathrm{I}^{2}=95.6\right)$ (Fig. 2). The pooled estimated CFR of COVID-19 in the patients admited to ICU was $37.0 \%$ (95\% CI: 24.051.0; $\left.\mathrm{P}<0.001, \mathrm{I}^{2}=97.8\right)$, and in patients younger than 50 years $3.0 \%$ (95\% CI: 0.0-6.0; $\left.\mathrm{P}<0.001, \mathrm{I}^{2}=99.2\right)$, while the CFR was $19.0 \%$ (95\% CI: $13.0-24.0 ; \mathrm{P}<0.001, \mathrm{I}^{2}=99.8$ ) in patients older than 50 years (Fig. 2 and Table 2). Based 
Fig. 2. The forest plot of estimated case fatality rate of COVID-19 in different subgroups.

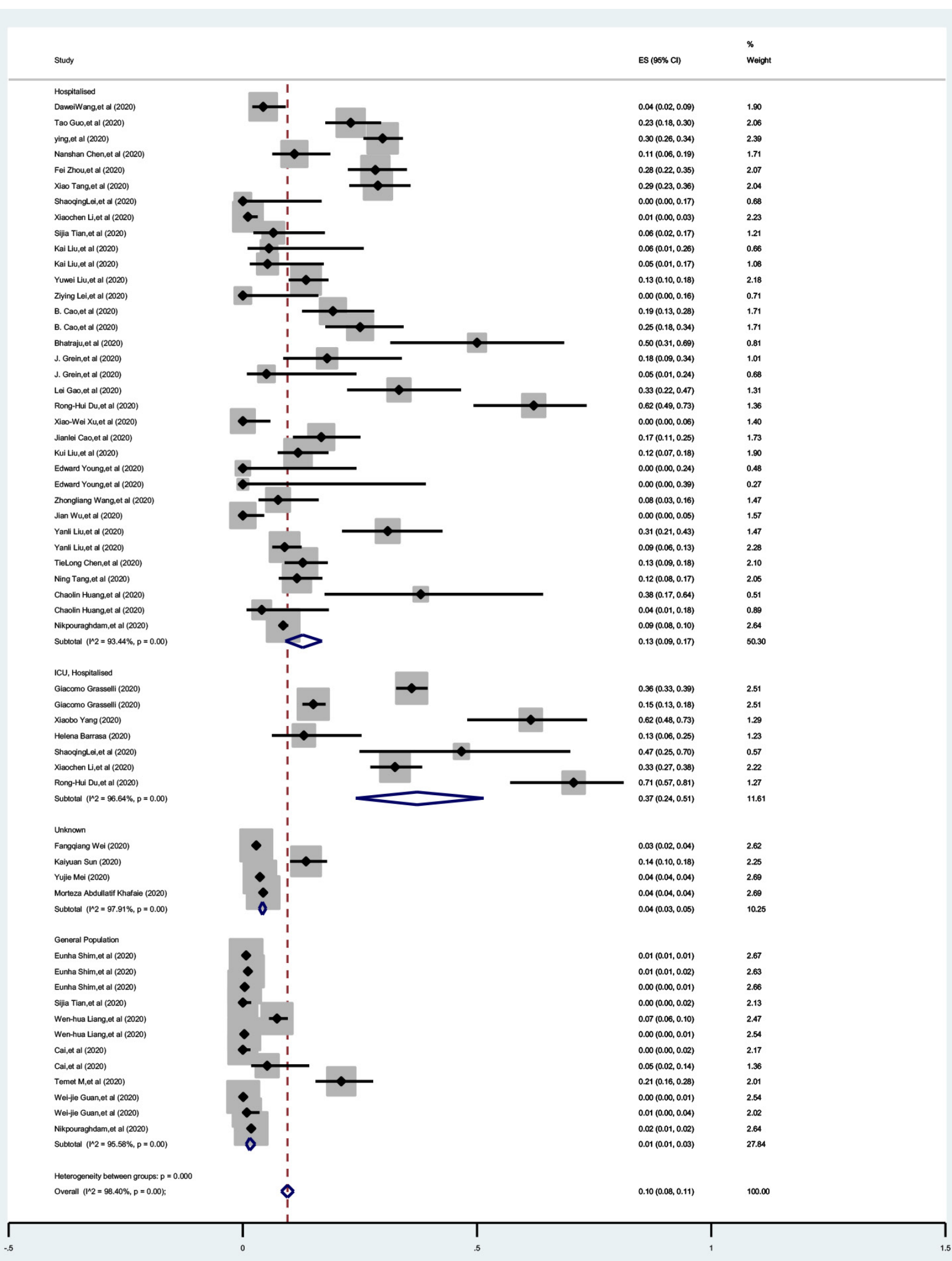


Fig. 3. The beggs funnel plot to assess publication bias

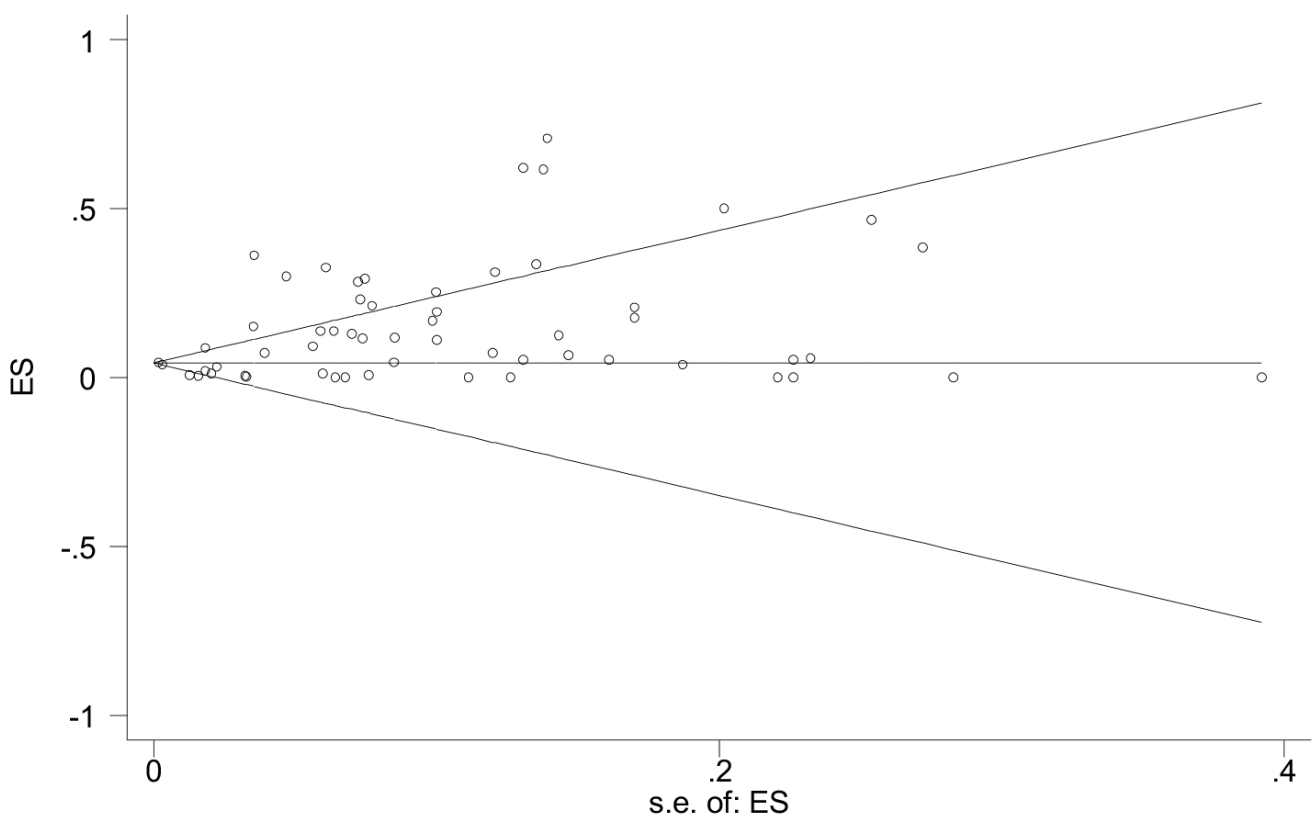

on Beggs test there was no publication bias $(\mathrm{P}=0.2)$, but the Eggers tests was shown the presence of publication bias $(\mathrm{P}<0.001)$. Moreover, based on metaregresion regression analysis, ample size was not significantly associated with heatrogeneity of pooled estimated CFR $(\mathrm{P}=0.31)($ Fig. 3).

\section{Discussion}

The present study systematically reviewed the available literature to estimate the overall pooled CFR COVID-19 and specific subpopulations in patients admitted in hospital, ICU, and old. Based on 39 studies that fulfilled this study, the overall estimated pooled CFR of COVID-19 was $10.0 \%$. The pooled CRF was only $1.0 \%$ in the general population, while $29 \%$ in patients admitted in ICU and $15 \%$ in hospitalized patients.

Although there is limited information on COVID-19 CFR, some primary studies have been reported CFR in different countries with various target populations. For example, the studies reported from Italy have indicated a 9.26\% CFR of COVID-19 [47, 50]. Moreover, studies reported from Spain and France have reported 6.16 and $4.21 \%$ CFR, respectively $[47,50]$. Furthermore, a study reported from Iran shown that $7.9 \%$ of CFR, while the study reported from Turkey indicated $2.0 \%$ CFR of COVD-19 [47, 50]. Compared to the previous studies cited above, our meta-analysis finding, based on primary studies reported from different countries, indicated CFR with a wide range. This difference between our CFR with its broad range and the previous study could be due to the target population difference.

Moreover, it might be due to case/death finding and reporting capacity between the countries where the primary studies were reported. Furthermore, case and death reporting in some countries might be influenced by political decisions. Thus, these probable reasons could affect the overall estimation of CFR, which could impact the actual epidemiological feature of the disease. CFR of COVID-19 ranges between 4 and 11\% among hospitalized adult patients in different countries based on previous studies [51]. The present study showed that high (13\%) CFR in hospital admitted patients. The present study was also revealed that CFR in patients admitted to ICU was $37 \%$. In contrast to our findings, a case series study reported from Seattle indicated high CFR (50\%) among critically ill patients [32]. Moreover, a study reported from Washington state the highest CFR (67\%) in patients admitted to ICU. Thus the health background of patients admitted to ICU could be an essential factor related to death [52]. For example, among patients admitted to ICU in Washington, $86 \%$ have comorbidities such as chronic kidney disease and congestive heart failure [52]. High CFR among patients admitted to ICU is mainly attributable to comorbidities and old age, which exacerbate the morbidity that leads to poor outcomes in patients admitted to ICU. Patients with comorbidities and old age demand great attention to recover from COVID-19, and more evidence requires better understanding to inform health care [32].

The present meta-analysis revealed a significant difference in CFR in the age group younger than 50 years and older (3.0 vs 19\%). In Italy, CFR was 52.3 in patients more aged than 80 years and 35.6 in $70-79$ years old [9]. Similarly, in Chinese, CFR was high among the most aging patients [53]. Besides CFR differences in age groups, the overall CFR reported from Italy (7.2\%) is substantially higher than in China $(2.3 \%)$ [9, 53]. The difference in CFR is not only related to age, rather other factors such as. Occupation, gender, and clinical 
comorbid could be contributed to high CFR in the old age group. A better method to preventing possible misconceptions about age effect on CFR in COVID-19 patients direct age adjustment could be a solution.

Several factors could affect on mortality of COVID-19 in different settings due to health system capacity, age variation, the burden of chronic diseases, perception regarding COVID-19, and other unknown factors. For instance, the majority of COVID-19 confirmed cases in Italy are in old proportion. Moreover, most deaths due to COVID-19 in Italy are among geriatric, male patients with comorbidity [9]. In addition, the number of symptoms the cases shown is probably affected by death due to COVID-19. For example, some patients have only one or three main symptoms of COVID-19, but some patients reveal more than three symptoms which most probably affects the death due to COVID-19. Thus, advanced, indepth analyses are required to explore the effect of the number of signs on fatalities associated with COVID-19. Prior findings suggested that CFR of COVID-19 seems to be less deadly compared to Bird flu, Ebola, SARS, and MERS , However, it becomes a global economic and public health concern $[47,54]$. In most patients, COVID-19 shows mild symptoms, which hid the burden of the disease and facilitate transmission in the community rapidly [47]. Thus, media should play a significant role in enhancing health literacy because the unique characteristics of COVID-19 make the general community at risk. Some undetected or delayed cases could probably lead to underestimation of CFR of COVID-19. Underestimation could be linked to the level of the general public and politicians' preparedness and mitigation.

\section{Conclusions}

The pooled estimate CFR of COVID-19 in this review is considerably high and differs between different patient groups. The CFR was higher in patients admitted in ICU and older than 50 years. Moreover, the present review results highlighted the need for transparency in testing and reporting policies and denominators used in CFR estimation. It is also necessary to report the case's age, sex, and comorbidity distribution of all patients, which is essential in comparing the CFR among different population segments.

\section{Ethics statement}

Ethics clearance was not sought because this review was based on published articles.

\section{Acknowledgements}

Funding sources: this research did not receive any specific grant from funding agencies in the public, commercial, or not-for-profit sectors.

\section{Conflict of interest statement}

The authors declare no conflict of interest.

\section{Authors' contributions}

YA and MS: conception of the idea, data analysis, Manuscript writing, HHT, AAGH and MJ: searching, data extraction, manuscript writing. All authors read and approved the final manuscript.

\section{References}

[1] Nikpouraghdam M, Farahani AJ, Alishiri G, Heydari S, Ebrahimnia M, Samadinia H, Sepandi M, Jafari NJ, Izadi M, Qazvini A. Epidemiological characteristics of coronavirus disease 2019 (COVID-19) patients in IRAN: a single center study. J Clin Virol 2020;127:104378. https://doi.org/10.1016/j.jcv.2020.104378

[2] Wu JT, Leung K, Bushman M, Kishore N, Niehus R, de Salazar PM, Cowling BJ, Lipsitch M, Leung GM. Estimating clinical severity of COVID-19 from the transmission dynamics in $\mathrm{Wu}$ han, China. Nat Med 2020;26:506-510. https://doi.org/10.1038/ s41591-020-0822-7

[3] Sun P, Lu X, Xu C, Sun W, Pan B. Understanding of COVID-19 based on current evidence. J Med Virol 2020;92:548-51. https:// doi.org/10.1002/jmv.25722

[4] Yang S, Cao P, Du P, Wu Z, Zhuang Z, Yang L, Yu X, Zhou $Q$, Feng $X$, Wang $X$. Early estimation of the case fatality rate of COVID-19 in mainland China: a data-driven analysis. Ann Transl Med 2020;8:128. https://doi.org/10.21037/ atm.2020.02.66

[5] Shim E, Tariq A, Choi W, Lee Y, Chowell G. Transmission potential and severity of COVID-19 in South Korea. Int J Infect Dis 2020;93:339-44. https://doi.org/10.1016/j.ijid.2020.03.031

[6] Wallinga J, Teunis P. Different epidemic curves for severe acute respiratory syndrome reveal similar impacts of control measures. Am J Epidemiol 2004;160:509-16. https://doi. org/10.1093/aje/kwh255

[7] Alimohamadi Y, Sepandi M: Basic reproduction number: an important indicator for the future of the COVID-19 epidemic in Iran. Journal Mil Med 2020;22:96-7. https://doi.org/10.30491/ JMM.22.1.96

[8] Alimohamadi Y, Taghdir M, Sepandi M. Estimate of the basic reproduction number for COVID-19: a systematic review and meta-analysis. J Prev Med Public Health 2020;53:151. https:// doi.org/10.3961/jpmph.20.076

[9] Onder G, Rezza G, Brusaferro S. Case-fatality rate and characteristics of patients dying in relation to COVID-19 in Italy. JAMA 2020;323:1775-6. https://doi.org/10.1001/jama.2020.4683

[10] Rajgor DD, Lee MH, Archuleta S, Bagdasarian N, Quek SC. The many estimates of the COVID-19 case fatality rate. Lancet Infect Dis 2020;20:776-7. https://doi.org/10.1016/S14733099(20)30244-9

[11] Russell TW, Hellewell J, Jarvis CI, Van Zandvoort K, Abbott S, Ratnayake R, Flasche S, Eggo RM, Edmunds WJ, Kucharski AJ. Estimating the infection and case fatality ratio for coronavirus disease (COVID-19) using age-adjusted data from the outbreak on the Diamond Princess cruise ship, February 2020. Eurosurveill 2020;25:2000256. https://doi.org/10.2807/15607917.ES.2020.25.12.2000256

[12] Wang D, Hu B, Hu C, Zhu F, Liu X, Zhang J, Wang B, Xiang $\mathrm{H}$, Cheng Z, Xiong Y. Clinical characteristics of 138 hospitalized patients with 2019 novel coronavirus-infected pneumonia in Wuhan, China. JAMA 2020;323:1061-9. https://doi. org/10.1001/jama.2020.1585 
[13] Wells GA, Shea B, O'connell D, Peterson J, Welch V, Losos M, Tugwell P. The Newcastle-Ottawa Scale (NOS) for assessing the quality of nonrandomised studies in meta-analyses. 2013 Available from: http://www.ohri.ca/programs/clinical_epidemiology/oxford.asp

[14] Grasselli G, Zangrillo A, Zanella A, Antonelli M, Cabrini L, Castelli A, Cereda D, Coluccello A, Foti G, Fumagalli R. Baseline characteristics and outcomes of 1591 patients infected with SARS-CoV-2 admitted to ICUs of the Lombardy region, Italy. JAMA 2020;323:1574-81. https://doi.org/10.1001/ jama.2020.5394

[15] Guo T, Fan Y, Chen M, Wu X, Zhang L, He T, Wang H, Wan J, Wang X, Lu Z. Cardiovascular implications of fatal outcomes of patients with coronavirus disease 2019 (COVID-19) JAMA Cardiol 2020;5:811-8. https://doi.org/10.1001/jamacardio.2020.1017

[16] Wang W, Tang J, Wei F. Updated understanding of the outbreak of 2019 novel coronavirus (2019-nCoV) in Wuhan, China. J Med Virol 2020;92:441-7. https://doi.org/10.1002/jmv.25689

[17] Tang N, Bai H, Chen X, Gong J, Li D, Sun Z, Anticoagulant treatment is associated with decreased mortality in severe coronavirus disease 2019 patients with coagulopathy. J Thromb Haemost 2020;18:1094-9. https://doi.org/10.1111/jth.14817

[18] Chen N, Zhou M, Dong X, Qu J, Gong F, Han Y, Qiu Y, Wang J, Liu Y, Wei Y. Epidemiological and clinical characteristics of 99 cases of 2019 novel coronavirus pneumonia in Wuhan, China: a descriptive study. Lancet 2020;395:507-13. https://doi. org/10.1016/S0140-6736(20)30211-7

[19] Yang X, Yu Y, Xu J, Shu H, Liu H, Wu Y, Zhang L, Yu Z, Fang $\mathrm{M}, \mathrm{Yu}$ T. Clinical course and outcomes of critically ill patients with SARS-CoV-2 pneumonia in Wuhan, China: a single-centered, retrospective, observational study. Lancet Respir Med 2020;8:475-81. https://doi.org/10.1016/S2213-2600(20)300795

[20] Zhou F, Yu T, Du R, Fan G, Liu Y, Liu Z, Xiang J, Wang Y, Song B, Gu X, Guan L, Wei Y, Li H, Wu X, Xu J, Tu S, Zhang Y, Chen $\mathrm{H}, \mathrm{Cao} \mathrm{B}$. Clinical course and risk factors for mortality of adult inpatients with COVID-19 in Wuhan, China: a retrospective cohort study. Lancet (London, England) 2020;395:1054-62. https://doi.org/10.1016/S0140-6736(20)30566-3

[21] Barrasa H, Rello J, Tejada S, Martín A, Balziskueta G, Vinuesa C, Fernández-Miret B, Villagra A, Vallejo A, San Sebastián A. SARS-CoV-2 in Spanish intensive care units: early experience with 15-day survival in Vitoria. Anaesth Crit Care Pain Med 2020;39:553-61. https://doi.org/10.1016/j.accpm.2020.04.001

[22] Tang X, Du R-H, Wang R, Cao T-Z, Guan L-L, Yang C-Q, Zhu Q, Hu M, Li X-Y, Li Y. Comparison of hospitalized patients with ARDS caused by COVID-19 and H1N1. Chest 2020;158:195205. https://doi.org/10.1016/j.chest.2020.03.032

[23] Lei S, Jiang F, Su W, Chen C, Chen J, Mei W, Zhan LY, Jia Y, Zhang L, Liu D, Xia ZY, Xia Z. Clinical characteristics and outcomes of patients undergoing surgeries during the incubation period of COVID-19 infection. EClinicalMedicine 2020;21:100331.

[24] Shim E, Tariq A, Choi W, Lee Y, Chowell G. Transmission potential and severity of COVID-19 in South Korea. Int J Infect Dis 2020;93:339-44. https://doi. org/10.1016/j.ijid.2020.03.031

[25] Li X, Xu S, Yu M, Wang K, Tao Y, Zhou Y, Shi J, Zhou M, Wu B, Yang Z. Risk factors for severity and mortality in adult COVID-19 inpatients in Wuhan. J Allergy Clin Immunol 2020;146:110-8. https://doi.org/10.1016/j.jaci.2020.04.006

[26] Tian S, Hu N, Lou J, Chen K, Kang X, Xiang Z, Chen H, Wang D, Liu N, Liu D, Chen G, Zhang Y, Li D, Li J, Lian H, Niu S, Zhang L, Zhang J. Characteristics of COVID-19 infection in Beijing. J Infect 2020;80:401-6. https://doi.org/10.1016/j. jinf.2020.02.018

[27] Liu K, Chen Y, Lin R, Han K. Clinical features of COVID-19 in elderly patients: a comparison with young and middle-aged patients. J Infect 2020;80:e14-8. https://doi.org/10.1016/j. jinf.2020.03.005

[28] Liu Y, Du X, Chen J, Jin Y, Peng L, Wang HH, Luo M, Chen L, Zhao Y. Neutrophil-to-lymphocyte ratio as an independent risk factor for mortality in hospitalized patients with COVID-19. J Infect 2020;81:e6-e12. https://doi.org/10.1016/j. jinf.2020.04.002

[29] Lei Z, Cao H, Jie Y, Huang Z, Guo X, Chen J, Peng L, Cao H, Dai X, Liu J, Li X, Zhu J, Xu W, Chen D, Gao Z, He JR, Lin BL. A cross-sectional comparison of epidemiological and clinical features of patients with coronavirus disease (COVID-19) in Wuhan and outside Wuhan, China. Travel Med Infect Dis 2020;35:101664. https://doi.org/10.1016/j.tmaid.2020.101664

[30] Sun K, Chen J, Viboud C. Early epidemiological analysis of the 2019-nCoV outbreak based on a crowdsourced data. MedRxiv 2020. https://doi.org/10.1101/2020.01.31.20019935

[31] Mei Y, Hu J. Preparedness is essential for Western Pacific Islands during the COVID-19 Pandemic. Disaster Med Public Health Prep 2020; Apr 16:1-11. https://doi.org/10.1017/dmp.2020.102

[32] Cao B, Wang Y, Wen D, Liu W, Wang J, Fan G, Ruan L, Song B, Cai Y, Wei M, Li X, Xia J, Chen N, Xiang J, Yu T, Bai T, Xie X, Zhang L, Li C, Yuan Y, Chen H, Li H, Huang H, Tu S, Gong F, Liu Y, Wei Y, Dong C, Zhou F, Gu X, Xu J, Liu Z, Zhang Y, Li H, Shang L, Wang K, Li K, Zhou X, Dong X, Qu Z, Lu S, Hu X, Ruan S, Luo S, Wu J, Peng L, Cheng F, Pan L, Zou J, Jia C, Wang J, Liu X, Wang S, Wu X, Ge Q, He J, Zhan H, Qiu F, Guo L, Huang C, Jaki T, Hayden FG, Horby PW, Zhang D, Wang C. A Trial of Lopinavir-Ritonavir in Adults Hospitalized with Severe COVID-19. N Engl J Med. 2020;382:1787-99. https:// doi.org/10.1056/NEJMoa2001282

[33] Bhatraju PK, Ghassemieh BJ, Nichols M, Kim R, Jerome KR, Nalla AK, Greninger AL, Pipavath S, Wurfel MM, Evans L. Covid-19 in critically ill patients in the Seattle region - case series. N Engl J Med 2020;382:2012-22. https://doi.org/10.1056/ NEJMoa2004500

[34] Grein J, Ohmagari N, Shin D, Diaz G, Asperges E, Castagna A, Feldt T, Green G, Green ML, Lescure F-X. Compassionate use of remdesivir for patients with severe Covid-19. N Engl J Med 2020;382:2327-36. https://doi.org/10.1056/NEJMoa2007016

[35] Liang W-h, Guan W-j, Li C-c, Li Y-m, Liang H-r, Zhao Y, Liu X-q, Sang L, Chen R-c, Tang C-1. Clinical characteristics and outcomes of hospitalised patients with COVID-19 treated in Hubei (epicentre) and outside Hubei (non-epicentre): a nationwide analysis of China. Eur Respir J 2020;55: 2000562. https:// doi.org/10.1183/13993003.00562-2020

[36] Gao L, Jiang D, Wen XS, Cheng XC, Sun M, He B, You LN, Lei P, Tan XW, Qin S, Cai GQ, Zhang DY. Prognostic value of NT-proBNP in patients with severe COVID-19. Respir Res 2020;21:83. https://doi.org/10.1186/s12931-020-01352-w

[37] Du R-H, Liu L-M, Yin W, Wang W, Guan L-L, Yuan M-L, Li Y-L, Hu Y, Li X-Y, Sun B. Hospitalization and critical care of 109 decedents with COVID-19 pneumonia in Wuhan, China. Ann Am Thorac Soc 2020;17:839-46. https://doi.org/10.1513/ AnnalsATS.202003-225OC

[38] Xu X-W, Wu X-X, Jiang X-G, Xu K-J, Ying L-J, Ma C-L, Li S-B, Wang H-Y, Zhang S, Gao H-N. Clinical findings in a group of patients infected with the 2019 novel coronavirus (SARSCov-2) outside of Wuhan, China: retrospective case series. BMJ 2020;368. https://doi.org/10.1136/bmj.m606

[39] Cai Q, Huang D, Ou P, Yu H, Zhu Z, Xia Z, Su Y, Ma Z, Zhang Y, Li Z. COVID-19 in a designated infectious diseases hospital outside Hubei Province, China. Allergy 2020;75:1742-52. https://doi.org/10.1111/all.14309

[40] Cao J, Tu W-J, Cheng W, Yu L, Liu Y-K, Hu X, Liu Q. Clinical features and short-term outcomes of 102 patients with coronavirus disease 2019 in Wuhan, China. Clin Infect Dis 2020;71:74855. https://doi.org/10.1093/cid/ciaa243

[41] Liu K, Fang YY, Deng Y, Liu W, Wang MF, Ma JP, Xiao W, Wang YN, Zhong MH, Li CH, Li GC, Liu HG. Clinical charac- 
teristics of novel coronavirus cases in tertiary hospitals in Hubei Province. Chin Med J (Engl) 2020, 5;133:1025-31. https://doi. org/ 10.1097/CM9.0000000000000744

[42] Young BE, Ong SWX, Kalimuddin S, Low JG, Tan SY, Loh J, Ng O-T, Marimuthu K, Ang LW, Mak TM. Epidemiologic features and clinical course of patients infected with SARSCoV-2 in Singapore. JAMA 2020;323:1488-94. https://doi. org/10.1001/jama.2020.3204

[43] Wang Z, Yang B, Li Q, Wen L, Zhang R. Clinical features of 69 cases with coronavirus disease 2019 in Wuhan, China. Clin Infect Dis 2020;71:769-77. https://doi.org/10.1093/cid/ciaa272

[44] McMichael TM, Currie DW, Clark S, Pogosjans S, Kay M, Schwartz NG, Lewis J, Baer A, Kawakami V, Lukoff MD. Epidemiology of Covid-19 in a long-term care facility in King County, Washington. N Engl J Med 2020;382:2005-11. https:// doi.org/10.1056/NEJMoa2005412

[45] Liu Y, Sun W, Guo Y, Chen L, Zhang L, Zhao S, Long D, Yu L. Association between platelet parameters and mortality in coronavirus disease 2019: retrospective cohort study. Platelets 2020;31:490-6. https://doi.org/10.1080/09537104.2020.17543 83

[46] Chen T, Dai Z, Mo P, Li X, Ma Z, Song S, Chen X, Luo M, Liang K, Gao S. Clinical characteristics and outcomes of older patients with coronavirus disease 2019 (COVID-19) in Wuhan, China: a single-centered, retrospective study. J Gerontol A Biol Sci Med Sci 2020;75:1788-95. https://doi.org/10.1093/gerona/ glaa089

[47] Tang N, Li D, Wang X, Sun Z. Abnormal coagulation parameters are associated with poor prognosis in patients with novel coronavirus pneumonia. J Thromb Haemost 2020;18:844-7. https://doi.org/10.1111/jth.14768

[48] Khafaie MA, Rahim F. Cross-country comparison of case fatality rates of COVID-19/SARS-COV-2. Osong Public Health Res Perspect 2020;11:74. https://doi.org/10.24171/j. phrp.2020.11.2.03

[49] Huang C, Wang Y, Li X, Ren L, Zhao J, Hu Y, Zhang L, Fan G, Xu J, Gu X. Clinical features of patients infected with 2019 novel coronavirus in Wuhan, China. Lancet 2020;395:497-506. https://doi.org/10.1016/S0140-6736(20)30183-5

[50] Guan W-j, Ni Z-y, Hu Y, Liang W-h, Ou C-q, He J-x, Liu L, Shan H, Lei C-1, Hui DS. Clinical characteristics of coronavirus disease 2019 in China. N Engl J Med 2020;382:1708-20. https://doi.org/10.1056/NEJMoa2002032

[51] COVID-19 Coronavirus Pandemic. Available at: https://www. worldometers.info/coronavirus (accessed on: June, 2020).

[52] Singhal T. A review of coronavirus disease-2019 (COVID-19). Indian J. Pediatr 2020:1-6. https://doi.org/10.1007/s12098-02003263-6

[53] Arentz M, Yim E, Klaff L, Lokhandwala S, Riedo FX, Chong M, Lee M. Characteristics and outcomes of 21 critically ill patients with COVID-19 in Washington State. JAMA 2020;323:1612-4. https://doi.org/10.1001/jama.2020.4326

[54] Surveillances V. The epidemiological characteristics of an outbreak of 2019 novel coronavirus diseases (COVID-19) - China, 2020. China CDC Eeekly 2020;2:113-22.

[55] He F, Deng Y, Li W. Coronavirus disease 2019: What we know? J Med Virol 2020;92:719-25. https://doi.org/10.1002/jmv.25766

Received on June 6, 2020. Accepted on May 5, 2021.

Correspondence: Mojtaba Sepandi, Health Research Center, Lifestyle Institute, Baqiyatallah University of Medical Sciences, Tehran, Iran., Iran Present address: Nosrati Alley, South Sheykhbahaee Ave, 143591-13189 Tehran, Iran - Tel.: +982187555521 - E-mail address: msepandi@bmsu.ac.ir

How to cite this article: Alimohamadi Y, Hailu Tola H, Abbasi-Ghahramanloo A, Janani M, Sepandi M. Case fatality rate of COVID-19: a systematic review and meta-analysis. J Prev Med Hyg 2021;62:E584-E320. https://doi.org/10.15167/2421-4248/jpmh2021.62.2.1627

(c) Copyright by Pacini Editore Srl, Pisa, Italy

This is an open access article distributed in accordance with the CC-BY-NC-ND (Creative Commons Attribution-NonCommercial-NoDerivatives 4.0 International) license. The article can be used by giving appropriate credit and mentioning the license, but only for non-commercial purposes and only in the original version. For further information: https://creativecommons.org/licenses/by-nc-nd/4.0/deed.en 